\title{
PEMBUATAN PAPAN PETUNJUK
}

\author{
EKA SERLI PRATIWI
}

9173770410318

ekaserlipratiwii@gmail.com

1. Bentuk Kegiatan

> Pembuatan Papan Petunjuk Arah.

2. Lokasi

$>$ Desa Bontocini.

3. Hari/Tanggal dan Waktu

$>$ Senin, 5 oktober 2020 - Selesai.

4. Peserta yang Dilibatkan

> Mahasiswa KKLP YAPTI JENEPONTO

$>$ Karang Taruna Desa Bontocini.

5. Alasan Diadakannya

> Alasan diadakannya yaitu karena tidak adanya petunjuk arah di beberapa jalan kecil di desa Bontocini.

6. Tujuan dan Manfaat

> Tujuan dan Manfaat dibuatnya petunjuk arah yaitu untuk memberikan informasi mengenai jalan-jalan kecil di desa Bontocini.

7. Produk yang Dihasilkan

$>$ Papan Petunjuk Arah sebanyak 5 buah.

8. Deskripsi Kegiatan

$>$ Pembuatan papan petunjuk arah ini dikerjakan selama 5 hari dan dipasang pada tanggal 12 oktober. Pembuatan papan petunjuk arah ini melewati beberapa proses pengerjaan salah satunya proses pengecetan. 